\title{
CINEMA EM LUKÁCS: A ATMOSFERA PSÍQUICA EM MOVIMENTO
}

\author{
[MOVIE THEATER IN LUKÁCS: THE MOVING PSYCHIC ATMOSPHERE]
}

\author{
José Deribaldo Gomes dos Santos * \\ Universidade Federal do Ceará, Brasil
}

\begin{abstract}
Resumo: O artigo dialoga com o debate empreendido por Lukács sobre cinema. Para esse autor, o filme é fruto de uma classe de reflexo que duplica a mimese. Opta-se, metodologicamente, por um estudo de caráter teórico-bibliográfico em que se opera uma leitura imanente de parte da Estética do húngaro. Sob tais orientações, a comunicação tematiza os principais pontos pelos quais Lukács ergue seu entendimento sobre a arte cinematográfica: 1) relação com o desenvolvimento da técnica; 2) autenticidade cinematográfica; 3) tendência a minimizar a objetividade indeterminada: labilidade e elasticidade; 4) atmosfera psíquica; 5) "linguagem" cinematográfica. A exposição entende que o cinema, embora tenha nascido como um produto do capitalismo desenvolvido, guarda a contradição de possuir elevado nível de realismo, ao mesmo tempo em que pode trafegar as mais tacanhas ideologias burguesas.

Palavras-chave: Cinema; Dupla mimese; Atmosfera cinematográfica; Lukács
\end{abstract}

ABstract: The article talks about Lukács debate about cinema. For this author, the film is the fruit of a class of reflection that duplicates mimesis. It is methodologically chosen for a theoretical-bibliographic study in which an immanent reading of the hungarian Aesthetics is performed. Under these guidelines, the communication discussion the main points by which Lukács raises his understanding on the cinematographic art: 1) relation with the development of the technique; 2) cinematographic authenticity; 3 ) tendency to minimize undetermined objectivity: lability and elasticity; 4) psychic atmosphere; 5) cinematic language. The exhibition understands that cinema, although born as a product of developed capitalism, holds the contradiction of having a high level of realism, while at the same time it can travel the most narrow bourgeois ideologies.

KeYwords: Cinema; Double mimesis; Cinematographic atmosphere; Lukacs

\section{INTRODUÇÃO}

Suponho que me entender não é uma questão de inteligência e sim de sentir, de entrar em contato...

Ou toca, ou não toca.

(Clarice Lispector)

$\mathrm{O}$ cinema é fruto de uma classe de reflexo que duplica a mimese. Ele possui, contudo, assim como os outros casos de mimese duplicada, elementos que

* Doutor em Educação Brasileira pela Universidade Federal do Ceará - UFC, Professor da Faculdade de Educação, Ciências e Letras do Sertão Central da Universidade Estadual do Ceará - FECLESC/UECE, do Programa de Pós-Graduação em Educação - PPGE/UECE e do Mestrado Acadêmico Intercampi em Educação e Ensino - MAIE/UECE. Bolsista de pósdoutorado da CAPES na Universidad Complutense de Madrid - UCM. E-mail: deribaldo.santos@uece.br. 
lhe garantem determinadas particularidades. Para se investigar a chamada sétima arte sob as orientações teóricas lukacsianas, opta-se por elencar alguns dos principais elementos que conferem ao meio fílmico suas decisivas particularidades. São eles: 1) relação com o desenvolvimento da técnica; 2) autenticidade cinematográfica; 3) tendência a minimizar a objetividade indeterminada: labilidade e elasticidade; 4)

134 atmosfera psíquica; 5) "linguagem" cinematográfica.

Para caminhar acerca desses pontos, duas questões precisam ser advertidas. Primeiramente que a concepção estético-cinematográfica de Lukács (1966, v.1, v.2; 1967 , v.3, v.4) não se resume a esses pontos. Em segundo lugar, essa divisão não pode ser abordada sem considerar uma constante e ineliminável dialética entre esses elementos, bem como entre eles e diversos outros pontos que se entrecruzam entre si. A presente comunicação, de caráter teórico e bibliográfico, declara que a opção em tematizar a problemática tendo como base seus pontos centrais, pretende somente criar melhores condições expositivas para que a compreensão leitora seja a mais clara possível sem, no entanto, desfocar a fidelidade ao autor húngaro. Compreende-se, portanto, que esse recorte deixará a exposição em melhores condições de analisar a importância do cinema para a vida humana segundo o entendimento de Georg Lukács.

Duplicação mimética em movimento, autenticidade e objetividade indeterminada na atmosfera anímica cinematográfica

\section{RELAÇÃO COM O DESENVOLVIMENTO DA TÉCNICA}

Comecemos pela relação que o cinema mantém com o desenvolvimento da técnica. Para atender a esse plano, iniciemos por alguns distanciamentos e algumas proximidades entre a arquitetura e o cinema. $\mathrm{Na}$ arquitetura, a duplicação mimética constrói-se sobre uma realidade concreta, cuja passagem ao estético não afeta o ser-emsi da construção real. Como nos diz Lukács (2013), o efeito evocativo-estético arquitetônico processa-se na segunda mimese. De modo distinto, o produto estético da técnica que possibilita o desenvolvimento do cinema é, desde o início, uma refiguração da realidade, nunca o real em sua concretude desantropomórfica. Nas construções, a duplicação mimética preserva o fato originário; mesmo que o efeito visual possa subsumir o meramente útil, a utilidade sempre estará em primeiro plano. A duplicação mimética do meio cinematográfico reflete um dado unitário da realidade, cuja refiguração anula qualquer rastro de sua gênese. Esse é o motivo pelo qual o processo estético aqui é completamente diferente do caso da arquitetura.

Há, no entanto, uma proximidade capital entre as duas artes. A evolução da base econômica criou, para ambas, a possibilidade de determinadas alternativas tecnológicas. Cada uma, à sua maneira específica de ser, abraçou essa possibilidade de modo que se pudesse cumprir sua missão social peculiar. Esse registro é importante, uma vez que há a identificação acrítica de que a evolução da técnica dá-se igual à artística. Tal identidade desfoca as fronteiras entre os elementos antropomorfizadores e os desantropomorfizadores presentes nos casos da arquitetura e do cinema. Vejamos: enquanto na arquitetura os elementos tecnológicos possibilitados pelo desenvolvimento da economia não apresentam caráter visual - a não ser secundariamente - na chamada sétima arte, a técnica fotográfica - seu elemento primário - é tão somente um reflexo visual da realidade. No caso arquitetônico, somente com a entrada da segunda mimese propriamente artística - depois que se cumprem as funções espaciais desantropomórficas, a conformação visual pode aparecer como elemento evocador. No caso da fotografia cinematográfica, o elemento fotografado desantropomorficamente é antropomoforfizado, mediado pelas situações vivenciadas pelo sujeito em seu cotidiano. Para ambas as artes, a passagem ao estético, que se dá pela duplicação mimética, apenas 
pode ocorrer sobre a base da técnica. Diferentemente da arquitetura, porém, o cine não cria simples e objetivamente a partir das alternativas que lhe impõe a tecnologia. Para que esta classe de reflexo produza seu efeito catártico, precisa considerar sua missão social. Em uma expressão: precisa fazer visível, desde o início, um mundo significativamente apropriado à sensibilidade humana, cujas legalidades estéticas imanentes de seu meio homogêneo ${ }^{1}$ possam dar mobilidade ao que é o verdadeiramente humano-social.

Definida essa distinção, já se pode tematizar a relação entre o cine e a técnica. $\mathrm{O}$ decisivo para a mimese duplicada no cinema está no fato de que a fotografia em si possibilita um reflexo desantropomórfico da realidade. $O$ caráter estético contido na técnica cinematográfica duplica a mimese, possibilitando a superação da desantropomorfização presente na fotografia ${ }^{2}$. Com a superação, há uma maior proximidade entre o refigurado e a visualidade compartilhada pelos viventes na cotidianidade. Os efeitos que daqui se podem desencadear seriam impossíveis, como se demonstra, sem um determinado desenvolvimento da técnica, cuja altura tecnológica apenas pode ser alcançada sobre a base de um capitalismo altamente desenvolvido. No cinema, mais que em qualquer outra arte, a influência desse desenvolvimento sobre a refiguração artística é bem mais patente.

Dessa constatação, desprendem-se diversos desdobramentos capitais para o desenvolvimento do cinema como arte substantiva. O primeiro e mais importante é que, na gênese dessa arte, manifesta-se o seu caráter capitalista, ou seja, o cinema é, desde o início, como nos diz Lukács (2013, p. 85), intelectual e tecnicamente, um produto do capitalismo e isso tem como consequência "[...] que toda a produção cinematográfica está incondicionalmente subordinada aos interesses capitalistas". Com essa subordinação e considerando a decadência capitalista, a existência de ilhas de salvaguarda da autenticidade artística encontra maiores obstáculos de surgimento e manutenção. Dizer que elas não existem seria uma simplificação grosseira. As margens de manobras para a produção da arte cinematográfica autêntica são, no entanto, reduzidas em comparação com outras artes. Como cada arte específica tem especificidades peculiares, essas ilhas e suas margens de manobras precisam ser estudadas com radical distanciamento dos dogmatismos mecanicistas, bem como das fantasias idealistas.

O mais importante para o caso do cine é destacar que a segunda mimese se responsabiliza por realizar uma transformação qualitativamente distinta da primeira. Lukács dialoga com Walter Benjamin (2012) para melhor aclarar como se processa essa distinta transformação. O húngaro se apodera da diferenciação elaborada por Benjamin (2012) entre o ator teatral e o que atua na telona. Este, desde o princípio da elaboração da personagem, sustenta Lukács (2013), em desacordo com o filósofo alemão, apresenta-se no sentido de propor uma reelaboração possível do real. Seu trabalho é pôr em movimento, a serviço da interpretação e por meio de sua personagem, um conjunto de gestos, acenos mímicos, entre outros recursos que a totalidade de seu corpo permitir. Esse conjunto de elementos faz com que a interpretação do ator cinematográfico seja qualitativamente diferente da do teatro.

Um segundo ponto em que há desencontro entre os dois filósofos refere-se ao que Benjamin (2012) chama de 'aura'. Para ele, a falta de contato entre o público e o ator - como ocorre no teatro - nega o caráter de irrepetibilidade que se produz na 'aura' teatral. Para Lukács (2013), o que se cria entre o ator do cine e o público é uma relação de novo tipo, ou seja, mesmo que esta atuação não seja, como no teatro, diretamente uma ação humana presente e sem mediações tecnológicas profundas, permanece uma relação entre pessoas; isto é, o ator do cinema representa uma pessoa em ação. Para reforçar seu argumento, o húngaro ainda lembra que em um quadro também se encontram refigurações de pessoas que não estão imediatamente presentes. Não 
obstante, não é esse o fato decisivo para que o citado quadro se converta, ou não, em arte autêntica.

\section{AUTENTICIDADE CINEMATOGRÁFICA}

A qualidade distintiva entre as atuações teatrais e as cinematográficas possibilita que se tematize a grande autenticidade possível ao reflexo fílmico. O meio homogêneo presente nesta classe de reflexo, em consequência de sua grande proximidade ao cotidiano, carrega consigo uma enorme possibilidade de autenticidade. A lente da câmera fotográfica, como entende Lukács (2013), é impessoal e infalível. Toda fotografia, independente de ser artística ou não, revela, necessariamente, o objeto que fotografou. Quando se trata da produção de um efeito chocante, no momento em que se fotografa um dado qualquer, a impressão que se pretende causar com o resultado da refiguração, precisa ser referenciado ao objeto que o gerou. Há, inclusive, a utilização da fotografia como elemento científico para registro documental, entre outras utilizações do resultado da foto. Em casos como esses, é muito importante a fidelidade ao objeto fotografado. As fotografias encontradas nos filmes, ao contrário, não exigem da fonte fotográfica fidelidade mecânico-ótico da realidade. Mesmo dispensando a precisão em relação ao objeto dado, a movimentação instantânea cinematográfica não pode prescindir da autenticidade do que se refigura.

O que o esteta acentua aqui é de vital importância para o prosseguimento da presente exposição. O reflexo captado pela fotografia fílmica, como o sabemos, pertence diretamente à realidade; não é, porém, como no caso da foto mecânica-ótico, a realidade concretamente dada. Como refigura a realidade de um modo mecanicamente fiel, originariamente desantropomórfica, a fotografia cinematográfica, contudo, ao fixar o fotografado, precisa, ao mesmo tempo, conservar por meio da duplicação mimética a autenticidade da realidade. Essa segunda mimese, por ter natureza artística, antropomorfiza o material que recebe do registro mecânico-ótico.

Quando o receptor é submetido ao efeito proporcionado pela fotografia fílmica já antropomorfizada - quando ele se vê diante da fidelidade por um lado e a autenticidade por outro; o acento emotivo causado pelo efeito recai sobre o elemento da autenticidade: recai sobre a segunda mimese, pois esta é antropomórfica. O húngaro denomina esse efeito de atmosfera anímica. Para o autor, isso ocorre em consequência da proximidade tempo-espacial que o cinema mantém como a vida cotidiana. Como a fonte dessa autenticidade é a cotidianidade, solo de onde brotam as inspirações que alimentam o reflexo cinematográfico, o selo de autêntico assume o papel essencial do meio homogêneo da chamada sétima arte. Isto é, o que foi fotografado apenas pode se tornar sensível como elemento especificamente visual do objeto dado se ele for um ser real e objetivamente presente. Acresce-se a isso o seguinte: a qualidade que garante a autenticidade está determinada já pela estrutura do dado captado da realidade, vinda, por seu turno, do cotidiano. Para se exemplificar essa autenticidade e, assim, reforçar a argumentação, pensemos no exemplo de uma fotografia que, mesmo sendo considerada de baixa qualidade artística, não pode perder, contudo, seu selo de autêntica, visto que o fotografado não se desfaz: fica registrado como dado real. Soma-se a isso o fato que, em contrapartida às outras artes visuais, no filme, do mesmo modo como ocorre na vida concreta, a visualidade e o decurso temporal real andam juntas e o tempo presente é um momento da realidade que registra a transição entre o passado e o futuro. Esse conjunto de fatores, portanto, garante ao filme sua grande estampa de autenticidade.

Sobre o aclaramento de como a relação entre fidelidade fotográfica e proximidade com o cotidiano patenteia a autenticidade fílmica, abre-se a condição para que o debate enfrente a tendência, presente nessa classe de reflexo, de produzir certa 
minimização da objetividade indeterminada ${ }^{3}$.

\section{TENDÊNCIA A MINIMIZAR A OBJETIVIDADE INDETERMINADA: LABILIDADE E ELASTICIDADE}

Para que essa tematização se sustente adequadamente, utiliza-se como recurso de exposição a proximidade entre o cinema e as artes plásticas. Nesta classe de reflexo artístico, a conformação apenas pode atingir seu objetivo quando dá forma a pessoas, animais, plantas, coisas e relações entre tais elementos. Essa refiguração, para se sustentar como estética, assume um caráter eminentemente de objetividade indeterminada, ou seja, um pé ou uma mão humana não são necessariamente um membro do corpo, uma morte não é um óbito real, entre outros exemplos. Enquanto um reflexo visual, o filme não tem como suportar essa indeterminabilidade objetiva. A proximidade à vida, mais a foto de imagens refletidas que conservam determinado nível de fidelidade, articuladas ao acompanhamento do decurso temporal, produz a tendência a se minimizar a objetividade indeterminada no cinema. Isto é, no cinema, em decorrências de sua estrutura estético-evocativa de visualidade articulada à temporalidade, que se apoia em uma fotografia manifestadamente próxima à vida real, o que ocorre na telona precisa, para assaltar catarticamente seu receptor, minimizar a objetividade indeterminada característica do campo artístico. Como arremata Lukács (2013, p. 95): “A autenticidade do ser-fotografado cria um meio homogêneo que aproxima o "mundo" configurado ao do cotidiano muito mais intensamente do que é possível e admissível nas outras artes."

O que significa, então, a proximidade do cinema à vida? Como explica Lukács (2013, p. 91), “[...] significa, pois, uma tendência a uma vida dada, tanto quanto possível, de modo imediatamente transparente e panorâmico, uma exigência sempre presente para o homem do cotidiano em relação ao seu entorno." Estando claro o que o autor entende por proximidade entre o filme e a vida, vejamos, por intermédio da exemplificação do cinema mudo, como o filósofo ilustra sua tese de que o reflexo fílmico produz a tendência à minimização da objetividade indeterminada. $\mathrm{O}$ cinema mudo para realizar a minimização e dar precisão ao sentido factual da tonalidade atmosférica anímica do filme, recorre a mensagens de textos expostas ao pé da tela, bem como ao acompanhamento musical, para dar sentido ao sequenciamento da visualidade. Sua intenção é enlaçar o todo da atmosfera psíquica transcorrida na telona. $\mathrm{Na}$ música e na pintura - com derivadas mediações nas demais artes - não há essa proximidade à autenticidade da vida cotidiana que a atmosfera anímica do filme consegue produzir.

A minimização da objetividade indeterminada, motivada pela proximidade que o filme guarda com a vida, determina as questões decisivas do estilo próprio ao reflexo cinematográfico. Entre essas questões estilísticas decisivas, importa tematizar dois elementos que têm importantíssimas consequências para a principal contradição em que se sustenta o reflexo fílmico: a questão da labilidade e da elasticidade. Como ilustra Lukács (2013, p. 91), no cinema

a elasticidade do meio homogêneo é tão acentuada que muitas vezes transpassa para uma elevada labilidade, já porque a segunda imediaticidade da configuração artística deve se reaproximar tanto da imediaticidade da vida. O lado subjetivo dessa constelação corresponde exatamente a sua essência objetiva: a transformação do homem inteiro do cotidiano no homem inteiramente, orientado ao próprio mundo do meio homogêneo, é aqui muito menos brusca, se mostra menos como um salto, do que em todas as outras artes. 
O fato de ser elástica por um lado e lábil por outro, confere ao reflexo fílmico a seguinte especificidade, a saber, uma multiplicidade ilimitada de possibilidades. Exatamente essa especificidade, associada a uma sensibilíssima proximidade à vida, confere ao meio do cinema a possibilidade - somente a possibilidade - de ser, ao mesmo tempo, uma arte popular autêntica e de grande dimensão. Do mesmo modo em que possui ilimitadas possibilidades de se tornar um veículo autenticamente artístico das aspirações das massas trabalhadoras; essa mesma ilimitada possibilidade, no entanto, condiciona o seu maior obstáculo. Para que se compreenda de modo profícuo essa contradição, torna-se necessário que se explique, com um pouco mais de elementos, como funciona a elasticidade e a labilidade.

Ao se dizer que o meio homogêneo cinematográfico é lábil, expressa-se que, nessa classe de reflexo, a transição entre o homem-inteiro e o homem-inteiramente ${ }^{4}$ é mais lisa e mais fácil que nas outras conformações artísticas. Isso torna possível a refiguração de um mundo onde a multiplicidade sem limites dos modos de conformação fílmicos, acaba por satisfazer as necessidades mais privadas que acometem o receptor, por exemplo, seus sonhos e instintos de diversas ordens. Essa possibilidade abre a fresta para que a tensão entre elementos grotescos, poéticos, engraçados, tristes etc., possam se fazer presentes na mesma medida que a mais abissal cafonice depressiva ou o mais sangrento e violento sadismo. A elasticidade, por sua vez, é a capacidade de fazer com que o homem-inteiro passe, relativamente completo, ao homem-inteiramente. $\mathrm{O}$ abando da imediaticidade da vida cotidiana, que salta o homem-inteiro para um patamar superior de reflexão possibilitando que ele ultrapasse a cotidianidade, mesmo sendo um efeito momentâneo, por seu caráter elástico, pode refigurar o cotidiano de modo que ele se encha de sensibilidade poética sem, no entanto, se carregar do naturalismo detalhista da vida cotidiana. A associação do caráter lábil com o elástico no cinema, significa, segundo sustenta Lukács (2013, p. 96), "[...] que o filme tem igualmente a possibilidade de vir a ser uma autêntica e grande arte popular, que ele pode se tornar uma expressão arrebatadora e compreensível para as grandes massas de sentimentos populares profundos e universais."

Já se pode retomar a contradição cinematográfica. Como arte temporal da visualidade, em que há um acompanhamento móvel de natureza auditiva, o cinema é a expressão sensível que possui um maior espaço de possibilidades. Ela não consegue, no entanto, como a literatura, a música e a pintura, por exemplo, conformar a vida espiritual do sujeito humano em sua mais profunda interioridade. Isso se deve, cada uma a seu modo específico de refigurar o real, ao fato de que essas artes conformam o material vital sob a ordenação da objetividade indeterminada, ou seja, refiguram um dado da realidade demonstrando, por meio da obra, que o elemento artístico não é a objetividade real, senão sua conformação estética. O que mais importa registrar aqui é que, a arte cinematográfica, para realizar seu amplo espaço de possibilidades ilimitadas, precisa minimizar a objetividade indeterminada, ou seja, reduzir, por meio da refiguração, a distância entre a imagem em movimento e a vida objetiva. Se renunciar a essa minimização, não conseguirá caracterizar o sujeito vivente determinado por uma situação humanamente dada. A poesia, por exemplo, por meio de sua construção que precisa das palavras, atinge aquilo que Santos (2018) chamou de cume da racionalidade humana. A poesia que se oferece, portanto, ao meio homogêneo da literatura, cria a possibilidade de se refigurar os dramas e destinos do espírito humano em sua mais profunda problemática, pois aqui, mesmo com o uso de conceitos linguísticos, a objetividade é indeterminada. Como entende Lukács (2013, p. 98-9): a "[...] atmosfera da composição verbal poética está obrigatoriamente ausente do filme", uma vez que no cinema se minimiza a objetividade indeterminada.

Conforme interpreta Duarte (2019, p. 71), a capacidade de simbolizar esteticamente a imagem em movimento, vinculando-a aos destinos humanos, cria, 
segundo a autora: "A potencialidade de [re]figurar o mundo humano partindo do solo da cotidianidade, sem ser mera descrição, mas trazendo à superfície da obra a subjetividade humano-genérica [...]". Isto é, retratar a realidade sem ser, por um lado, determinista e, por outro, sem se prender ao meramente subjetivo-individual do criador da obra (DUARTE, 2019).

Agora chegamos ao momento propício para resumir o que o autor chama de motor central dos efeitos cinematográficos e, com isso, apresentar algumas considerações a mais sobre o reflexo fílmico. Antes, contudo, para que a comunicação não careça de claridade, precisa-se retornar a uma questão que não se pode desviar, qual seja, o fato de que, em relação a atuação do ator no teatro, a interpretação das personagens no cinema representa algo radicalmente novo. $\mathrm{O}$ que se conquista com uma boa atuação no cinema torna-se definitivo, uma vez que, por meio da dupla mimese, a interpretação pessoal de quem atua, cria autonomamente, em cada caso dado, uma revelação sensível que se torna visual por intermédio da atuação. Em uma expressão: a atmosfera fílmica possibilita a criação de tipos humanos que se configuram como expressões de uma época ou de um estilo de vida, entre outros elementos. Isso se verificar ao se registrar que, em alguns casos de boas interpretações, há a produção de tipos que acabam por representar, por exemplo, determinado padrão comportamental que ganha lastro mundial. Nesses casos, como indica o húngaro, a atuação é capaz de recolher da cotidianidade um conjunto de propriedades humanas e convertê-las em uma tipicidade que, mesmo vinculada a pessoa que interpreta, assume uma vigência social ampla.

Para citarmos alguns exemplos utilizados pelo esteta magiar de intérpretes que logram essa tipicidade, reproduzimos os casos de Greta Garbo, em que aparece os ideias de beleza de uma época ou Asta Nielsen (Dia Asta), que encarnou a tragédia da condição feminina por meio do cinema mudo; mas se pode somar o caso de Gérard Philipe ao incorporar em seus personagens o valor e a agilidade moral e ainda o abarcante de Buster Keaton ${ }^{5}$. O papel que as boas e excelentes interpretações têm em cada película, sempre seguindo nosso autor, é apenas uma oportunidade, frequentemente um pretexto, para dar vida fílmica a uma determinada tipicidade que, por isso, está bem próxima ao povo do cotidiano. Para melhor exemplificar como uma atuação registra o típico, Lukács (2013, p. 102) utiliza-se de um clássico; escreve ele: "Conforme toda nossa exposição, é evidente que vemos em Chaplin o ponto culminante dessa tendência." O criador da personagem Carlitos, não elaborou suas interpretações com base na encarnação de diversos tipos de criação poética, como se pode ver em boas interpretações teatrais que precisam da criação da personagem dada antecipadamente pelo dramaturgo. No teatro, os grandes tipos que conseguem permanecer vivos na autoconsciência da humanidade, a exemplo, cada um a seu modo específico de conformar a realidade, de Hamalet, Falstaff, ou João Grilo, são personagens diversas criadas em épocas distintas pelo dramaturgo. Mesmo que muito importante para imortalizar a tipicidade, a interpretação teatral do ator não é o elo primordial para a criação do personagem típico; tal elo é produzido principalmente pelo dramaturgo. Mudando o que precisa ser mudado, isso vale também para a chamada música clássica, na música popular há outra relação impossível de se tratar agora. Chaplin, distintamente do caso do teatro, fez simbolicamente sensível, por meio de sua existência corporal, seu gestual

e sua mímica, tornou simbolicamente sensível um típico comportamento do "homem simples", do homem da multidão diante do capitalismo atual. Desse modo ele se elevou a uma tal altura típica na expressão da situação históricosocial que somente muito poucos contemporâneos foram capazes de alcançar em outras artes (LUKÁCS, 2013, p. 102). 


\section{ATMOSFERA PSÍQUICA}

Todas as condições estão dadas agora para que se possa adentrar ao tratamento do que o húngaro chama de veículo capital da receptividade cinematográfica, ou seja, a totalidade que se forma na atmosfera anímica. Então, o que seria essa tonalidade atmosférica psíquica? Lukács (2013), responde que o todo dos meios técnicos, a tomada cinematográfica, por exemplo, grandes planos, enquadramento, luz, fundo etc., apenas logram sentido estético como meio expressivo da unidade atmosférica; é por meio da transição de uma atmosfera a outra, por intermédio dos contrastes atmosféricos que a montagem, o corte, o ritmo, a velocidade dos movimentos, entre outros recursos cinematográficos conseguem "[...] conduzir os receptores de uma atmosfera anímica para outra no interior da atmosfera em última instância unitária do todo." (LUKÁCS, 2013, p. 103). O veículo principal da recepção fílmica é, portanto, o todo da tonalidade atmosférica anímica. Sobretudo nessa atmosfera psíquica, no seu particular valor de despertar no receptor uma autêntica representação fotográfica, o filme encontra suas limitações e, ao mesmo tempo, suas amplas possibilidades. Tal autenticidade, como anotado, é ausente nas demais artes. Nestas, a atmosfera que estamos debatendo, é apenas um momento, nunca o posto de predominante. Já no cinema, a atmosfera anímica, irradiada pela autenticidade do ser dos objetos refigurados, toma o posto de satisfazer, em primeiro lugar, as exigências estéticas que lhe cabem. Como escreve Lukács (2013, p. 104): “O receptor vivencia, portanto, o filme como a mediação de uma realidade que o impressiona como realidade imediata da vida."

Esse conjunto argumentativo é o que garante a atmosfera anímica o papel de categoria ativa universal que domina o meio fílmico. Não há como fugir do caráter de universalidade dessa atmosfera. Ela se processa desde o mais pastoso kitsch, passando pela mais constrangedora, cômica e amarga situação por que passa o vivente, até o mais elegante registro dos destinos, dramas e confusões autenticamente humanas. Tal universalidade, entre outros elementos, tem um decisivo peso no fato do cinema possuir uma grandiosa força ideológica, uma vez que a atmosfera produzida no cinema é responsável por penetrar todas as questões de visão de mundo do receptor, ou seja, tudo o que se refere aos posicionamentos do sujeito humano em relação aos acontecimentos de seu tempo.

Essa ideologia, contudo, tem uma peculiaridade que não se deve tergiversar, uma vez que ela, motivada principalmente pela atmosfera psíquica criada pelo cinema, parece emanar diretamente dos objetos concretos, das próprias coisas reais e presenciadas no cotidiano do receptor. Esse elemento concede à ideologia determinada força que a faz penetrar direta e imediatamente, e como ela age por intermédio dos atalhos emocionais, atua de modo que sua espontaneidade se faça inconsciente ao sujeito humano. Como resultado desse processo, em atendimento às exigências estéticas da atmosfera fílmica, que agrupa, sequencia e monta determinadas tomadas da realidade, produz-se a possibilidade de os elementos histórico-sociais penetrarem diretamente o núcleo espiritual do receptor, o que cria a possibilidade de a eficácia da influência ideológica sobre seus posicionamentos.

O tema da ideologia suscita que se registre a seguinte contradição presente no cinema: "E é essa inseparabilidade entre atmosfera anímica e conteúdo ideológico na vivência do expectador que faz do filme a arte mais popular de nossa época, a forma de expressão mais eficaz das mais diferentes e opostas tendências." (LUKÁCS, 2013, p. 105). O cinema, como registra Kracauer (1988), concentra, portanto, a tipicidade que movimenta as massas populares a assumirem espontaneamente posições em relação aos conflitos que a sociedade atravessa em um dado momento histórico.

Para que se entenda adequadamente o preciso caráter ideológico presente na chamada sétima arte, torna-se necessário dar claridade a uma fundamental contradição 
que se processa no cinema. Ao mesmo tempo que a fotografia, base artística do filme, pode atingir a evocação estética presente no campo da arte, aproxima-se perigosamente do naturalismo mais rasteiro e desprovido de força artística. Isso se justifica, uma vez que o meio imediato em que se desenvolve o filme é essencialmente uma informação que procura exatidão em relação à realidade; pois nele, como explica Lukács (2103, p. 106), "de fato, o relato, o documento, o doutrinário, o jornalismo podem transitar para a configuração artística tão discretamente, tão imperceptivelmente, que parece impossível identificar uma fronteira". Nesse aspecto, o húngaro concorda com Benjamin (2012) que, segundo o filósofo húngaro, percebeu com aguda sensibilidade o perigo que há na reelaboração do documento inicial que guarda a informação real, cuja mediação tecnológica pode violentar a autenticidade da reprodução. Apesar desse perigo, pensa Lukács (2013), é exatamente essa reelaboração das distintas e diversas formas fotográficas que sob o ordenamento da montagem e do sequenciamento - apenas possíveis ao meio homogêneo do filme - pode elevar a refiguração cinematográfica da imersão cotidiana ao nível exigido pela arte. Em uma frase: soerguer o sujeito humano da esfera da cotidianidade ao patamar de registro de sua autoconsciência.

Um fator a mais precisa ser registrado sobre esse debate: todas as características específicas da "linguagem" cinematográfica concentram a mesma problemática existente no interior da linguagem utilizada na vida cotidiana. Quando a análise recai sobre o debate acerca da verdade e da mentira, da veracidade e da falsidade, incluindo aqui todas as matrizes intermediárias entre esses dois extremos e, considerando que o filme é, como escrito, lábil e elástico, precisa-se entender melhor a contradição inerente a essa refiguração. Isto é, a característica que domina o campo do cinema, a tonalidade de sua atmosfera anímica, possui uma profundidade e uma amplitude que consegue tocar a autenticidade humana como não é possível às demais artes; mas, ao mesmo tempo e pelos mesmos motivos, o cinema permite uma extensíssima variabilidade que potencializa a esfera ideológica. O campo de batalha aqui é a utilização da capacidade tecnológica presente no espaço cinematográfico, não a técnica em si. Ela, por si só, não é benéfica ou maléfica, como demonstra Vieira Pinto (2008). O que se faz com a técnica e por meio dela é o elemento que deve ser analisado. O campo homogêneo do filme, contudo, apenas tem a potência que possui graças a sua dupla mimese, uma vez que a segunda é responsável por antropomorfizar o que a tecnologia desantropomórfica registra.

Usemos o exemplo da montagem para iluminar melhor a dialética presente no cinema. As produções fílmicas de êxito estético são aquelas em que a montagem é utilizada para além de sua condição meramente técnica; são aquelas em que a montagem é organizada de modo que possa fazer expressivos, estéticoideologicamente, a condição do princípio criador que o cinema possui. Na maioria das produções, no entanto, utiliza-se a montagem e os demais recursos tecnológicos pertencentes ao campo cinematográfico para dar visibilidade a películas que se orientam a trafegar a ideologia dominante. Para o húngaro, nesse debate também vale, uma vez efetuadas as mudanças necessárias, ao que se aplica à literatura, ou seja, a distinção entre narração e descrição. As produções realmente preocupadas em narrar, como escreve Lukács (2013, p. 107): utilizam-se das categorias estéticas gerais, adequada à peculiaridade fílmica, permitindo "[...] explicitar com detalhes o caráter artístico autêntico e verdadeiramente realista do filme, e assim libertar sua teoria e práxis de uma metafísica tecnicista-positivista da montagem."

\section{MEIO HOMOGÊNEO FÍLMICO: "LINGUAGEM" CINEMATOGRÁFICA}

Para atender adequadamente ao propósito desta comunicação e encaminhar 
nossas considerações para uma conclusão, necessário debater com o autor o papel desempenhado pela "linguagem" no filme ${ }^{6}$. Para dar conta desse debate, parte-se da dupla configuração com a qual o cinema mudo organiza sua conformação: por um lado, por meio de mensagens para comunicar ao receptor, usa-se a palavra cujo objetivo é informar ao espectador o que é imprescindível para a compreensão da trama; por outro lado, a música é utilizada como acompanhamento aditivo-evocador-estético para os fatos que se desenrolam na trama, seu objetivo é proporcionar ao receptor uma melhor condição de entendimento acerca da atmosfera emocional desenvolvida no filme. Duas das funções que a linguagem - sem aspas - cumpre no cine sonoro, pensa Lukács (2013), são continuações do modelo empregado pelo cinema mudo. Apenas como complemento desses dois momentos pode aparecer, em primeiro plano, o terceiro: "a linguagem como monólogo, diálogo, discurso etc., isto é, como elemento da tarefa do filme de, por meio da ação, vivificar imediatamente destinos humanos." (LUKÁCS, 2013, p. 108)

Dessas três questões a que mais importa, para que se demonstre o salto que o desenvolvimento da atmosfera anímica do cinema falado tem em relação ao modelo anterior, é justamente o terceiro e último: o diálogo. Daqui desdobram-se três novos elementos que se intercalam no movimento da audiovisualidade cinematográfica: primeiro, a comunicação, por meio do diálogo direto entre duas pessoas, de fatos imprescindíveis para o desenrolar da trama; segundo, a conversão da palavra falada, que agora se articula aos demais sons e ruídos componentes do acompanhamento atmosférico do visualmente evocado; terceiro e último, a palavra se articula a elementos dramáticos do todo da ação.

Explicando com mais detalhes cada um desses três novos momentos assumidos pelo cinema-sonoro possibilitados pelo diálogo. Com relação à primeira questão, ou seja, o diálogo falado diretamente entre personagens, Lukács (2013, p. 108) assim escreve:

\begin{abstract}
Enquanto na épica esse dar-a-conhecer constitui uma parte essencial da própria tensão narrativa, enquanto no drama a exposição forma uma unidade orgânica com a estrutura do desenvolvimento dialogal do destino, em cada filme devem ser descobertos novos caminhos para a solução desse problema. Como aqui a palavra falada não está no centro do meio homogêneo, e por consequência só pode emergir como complemento dos acontecimentos representados de modo audiovisual, o modo de associar o máximo necessário de informação com um mínimo de estorvo prosaico da atmosfera anímica se põe a cada vez como uma questão dramatúrgico-composicional particular.
\end{abstract}

Já ao que se refere ao segundo elemento, a conversão da palavra em sons da totalidade do andamento da trama, o autor considera que esse é o elemento que melhor registra o salto entre a nova forma cinematográfica e o cinema mudo. Apenas o filme sonoro consegue reproduzir a totalidade dos ruídos, incluindo as falas das personagens, em articulação ao acompanhamento musical. Elandia Duarte (2019), ao interpretar como o autor húngaro monta a estrutura estética cinematográfica, entende que em Lukács há uma unificação de todos os elementos do filme: "som, ângulos das imagens, cortes, cores, cenários, figurinos etc., enfim, todos os aspectos do filme devem confluir para se criar um mundo subjetivo que vá além do puramente imagético". Essa articulação audiovisual com o todo dos ruídos ambientais acompanhados por determinada música que, para dar maior força realista à atmosfera realista do filme, absorve o diálogo humano em uma totalidade compositiva sem distinção entre as partes.

Para o húngaro, quando se considera a evolução do cinema até os dias atuais, no entanto, é seguro afiançar que a conformação cinematográfica não pode dispensar o 
acompanhamento musical; o filme, mesmo sonoro, para melhor conformar a atmosfera visual, carece de um acompanhamento em forma de música. Duarte (2019, p. 81) entende que o cinema como imagem-sonora em movimento, absorve também o filme mudo também como sonoro, ainda que isso seja pela marcação da ausência de som. Disso se desprende que o papel do som no cinema vai além de trilha sonora musical. Essa autora cita como exemplo os filmes dos irmãos Luc e Jean-Pierre Dardenne. Nesses criadores, segundo entende Duarte (2019, p. 81), o som emerge de dentro da atmosfera anímica, contribuindo desse modo, "[...] não para a minimização da preponderância ontológica da imagem no cinema, mas na ênfase da sua relação dialética e direta com o a sonoridade".

Lukács (2013) explica que a necessidade do filme, mesmo o cinema falado, tem da existência de uma trilha sonora, está relacionada ao caráter de objetividade indeterminada que reside no cinema. A música, por meio da duplicação de sua mimese, entre todas as artes, é aquela que possui maior objetividade indeterminada. Como debatido na presente comunicação, o cinema, ao contrário, minimiza sua objetividade indeterminada. Nada mais adequado, para equilibrar essa indeterminalidade da objetividade, colhida de uma conformação externa produzida pelo filme, do que um acompanhamento musical que, por meio de sua duplicação mimética e força refigurativa, tende a conformar a mais profunda intimidade humana, o que a distancia, portanto, do mundo externo ao sujeito humano. No cinema, diferente das demais artes visuais, conforme aprofunda Duarte (2019), a indeterminação da objetividade tem, por intermédio do desenho de som do filme, a oportunidade de construir profundo diálogo com a determinação objetiva. Isso se processa, como prossegue a pesquisadora, por meio de narrações orais com voz de personagem presente ou ausente, acompanhamento sonoro, trilha musical, entre outros aspectos. Esses elementos, articulados a aspectos externos ao desenho sonoro, dão ao filme a condição de compor sua atmosfera anímica. Um bom exemplo dessa conexão, ainda seguindo a interpretação de Duarte (2019) é o letreiro final do filme Dançando no escuro (2000) de Lars Von Trier. Como entende a interprete, sem tal letreiro "[...] toda a película teria um sentido totalmente diferente" (DUARTE, 2019, p. 75). Como conclui a pesquisadora:

Fica claro, que uma obra cinematográfica que se alça a arte autêntica, consegue que todos os seus elementos: som, atuação, cenários, figurinos, cor etc., construam uma unicidade capaz de aferir integridade e poesia a obra finalizada, constituindo a atmosfera anímica do filme (DUARTE, 2019, p. 81-2).

Para concluir os três elementos sobre a "linguagem" fílmica, falta tocar na questão da palavra como componente dramático da trama. Imaginemos, para ilustrar, uma cena entre duas pessoas que dialogam fervorosamente sobre posições divergentes e que ambas se utilizam de mentiras para convencer seu interlocutor. Para que o receptor se convença da autenticidade da discussão entre as personagens e, assim, comova-se diante da situação, como escreve Lukács (2013), as interpretações precisam levar, por meio do contraste de palavras afiadas, até as últimas consequências suas convicções anímicas. Também se pode pensar em casos onde a personagem precisa comunicar algo de sua mais completa convicção e, sendo assim, necessita escolher adequadamente cada palavra a ser proferida. Esses exemplos, como entende o esteta, são suficientes para que se compreenda que o cinema precisa preparar cuidadosamente sua composição atmosférica, uma vez que é necessário se respeitar o que rege o filme: seus elementos tempo-espaciais. Como insiste Lukács (2013, p. 109): “[...] aqui é imprescindível um vínculo orgânico com a atmosfera audiovisual".

Para ilustrar suas argumentações, mais uma vez, Lukács (2013, p. 109), lança mão de um clássico: 
Pense-se no grande discurso pacifista-humanista que Chaplin pronuncia no final de $O$ Ditador. Sem dúvida seria fácil resumir seu sentido. Mas sua duração, seu tom etc. são condicionados pela atmosfera fundamental de todo o filme: como desfecho humano do pesadelo que vivemos com a guerra e o hitlerismo; também não é de modo algum casual que na configuração cinematográfica dos efeitos desse discurso tenha sido novamente introduzido um acompanhamento musical. Apesar de Chaplin ter certamente projetado também um acerto de contas intelectual com o sistema da desumanidade fascista, este transita, de modo imperceptível - e objetivamente é certo que não por acaso - para o puramente emocional.

Um exemplo menos clássico, porém mais contemporâneo, pode ser verificado por meio da produção $O$ quarto de Jack (2015) ${ }^{7}$. Aos 58 minutos da película, um menino que jamais havia saído de um pequeno quarto, após fugir do cativeiro, ao ser encontrado por policiais e ser conduzido ao local onde provavelmente sua mãe está prisioneira, a criança de seis anos assiste a mãe ser libertada do quarto onde deu à luz o filho. A tomada se posiciona dentro da viatura da polícia que registra o momento em que a mulher, ao sair de onde estava aprisionada, corre desesperadamente na direção da viatura policial. As únicas palavras que ela diz é: "cadê ele. Onde está meu filho". Por sua vez, o garoto fala apenas: "Mãe!". Do instante em que a mulher irrompe na frente do quarto até o momento em que a porta da viatura se abre para que mãe e filho se abracem, transcorrem-se não mais que trinta segundos. Em parte desse tempo a cena se passa em câmera lenta. Tudo isso em meio ao ruído da rua, das sirenes, dos áudios dos rádios das viaturas e das falas entre os policiais. Certo momento, esses ruídos são secundarizados por um som de um piano que assume o protagonismo sonoro - aqui, até o silêncio é utilizado como substrato psíquico. Toda essa narração é o que o autor denomina de atmosfera anímica, que é, insistimos, o princípio da composição cinematográfica. Tal princípio, nada mais claro, pois trata de destinos, paixões e emoções humanas, dar-se sobre intensos contrastes.

Notas conclusivas

O húngaro considera que o caminho da trivialidade é trilhado pela maioria das produções cinematográficas. A maior parte dos filmes que consegue um nível de autenticidade artística, aqueles considerados, de modo geral, como de boa qualidade fílmica, logram esse patamar por se elevarem por cima da média cotidiana. Esse distanciamento da cotidianidade, entretanto, apresenta o risco de que a produção logre êxito exatamente por se distanciar dos sentimentos mais profundos dos sujeitos viventes do cotidiano. Quando conseguem alcançar a profundidade que toca realmente as massas, o fazem por meios periféricos e, frequentemente, por intermédio de desvios excêntricos. Mais uma vez não se pode investigar essa questão com a rigorosidade mecânica, tampouco sob o 'olhar' relativista do idealismo. O que importa registrar é que a maioria das produções do cinema, "[...] ancora sua unidade apenas nos carecimentos sociais mais rudes, para cuja satisfação eles são criados, e seu público reage a eles de modo preponderantemente determinado pelo conteúdo ou pelos momentos de tensão puramente exteriores" (LUKÁCS, 2013, p. 109).

Entre os dois polos extremos apontados acima há, naturalmente, muitas realizações fílmicas que conseguem resultados expressivos. Necessário seria pesquisar essas questões com mais acuidade. Aqui, apenas é possível se tocar na contraposição potencializada pelo meio homogêneo fílmico que produz por um lado uma elasticidade e, por outro, uma labilidade. Esses dois elementos, associados à grande proximidade com o modo vivencial do cotidiano, que, por sua vez, é possibilitada pela dupla mimese, potencializa o cinema para ser uma arte autêntica que possa dar vazão aos mais profundos e decisivos conflitos sociais e, ao mesmo tempo, expressar os mais grotescos e rasteiros desejos humanos. Esse conjunto de fatores abre a porta para que a ideologia 
burguesa, dominante no período de capitalismo decadente, possa trafegar pelo cinema suas mais mesquinhas necessidades.

No cinema, muito mais que em qualquer outra arte, como nos informa Duarte (2019, p. 82), “[...] a homogeneidade do todo com as partes, principalmente pela introdução da duplicação mimética-tecnológica, se faz indispensável a sua configuração mimética". É por meio dessa coesão estética que confere realismo psíquico a atmosfera anímica cinematográfica, não obstante, “[...] que inúmeras ideologias podem ser repassadas, sendo conferido caráter de naturalidade às mesmas (DUARTE, 2019, p. 812). Tais desdobramentos ideológicos, de modo geral e em sua maioria, são apoderados pelas necessidades capitalistas para reproduzir suas incredulidades nas telas de cinema.

Como forma de dar um fechamento a nossa exposição sobre a análise de Lukács (1966, v.1, v.2; 1967, v.3, v.4) acerca da arte cinematográfica, sem necessariamente finalizar o debate, consideremos que a atmosfera estético-cinematográfica é edificada justamente sobre a base capitalista. Não se pode escamotear o fato de que o nascimento do cinema se processa sob o desenvolvimento tecnológico do capitalismo. Isso implica diretamente nas possibilidades postas à produção cinematográfica. Isto é, para que se possa realizar cinema, há a necessidade de uma determinada quantidade de capital. No desdobrar da decadência ideológica capitalista que atinge o que Mészáros (2000) denomina de crise estrutural do capital, em que os elementos civilizatórios do capitalismo vão, crescentemente, extinguindo-se, para que a produção do cinema se realize, tornam-se necessárias vultosas quantias.

Esse quadro, entre outros elementos impossíveis de serem tratados aqui, põe a produção cinematográfica sob dependência das organizações detentoras do capital financeiro que, via de regra, são comandadas por agentes econômicos que apenas enxergam a chamada sétima arte como forma de multiplicar capital. Mesmo que se possa comemorar o fato de a existência de ilhas de salvaguarda que produzem filmes de inegável qualidade; não obstante, como nos alerta a agudeza argumentativa de Lukács (2013), uma arte com potente capacidade a tipificar o autenticamente humano, podendo reproduzir o mais típico existente na popularidade cotidiana, na maioria das vezes, acaba por se subsumir no meramente agradável e, de modo geral e quando muito, desemboca na cafonice depressiva dos problemas imediatos da personalidade privada.

\section{REFERÊNCIAS}

BENJAMIN, Walter. Magia e técnica, arte e política: ensaios sobre literatura e história da cultura. São Paulo: Brasiliense, 2012.

DUARTE, Elandia Ferreira. Cinema e educação: uma crítica onto-materialista. Dissertação apresentada ao Curso de Mestrado Acadêmico em Educação do Programa de PósGraduação em Educação do Centro de Educação da Universidade Estadual do Ceará, 2019.

KRACAUER, Siegfried. De Caligari a Hitler: uma história psicológica do cinema alemão. Rio de Janeiro, Zahar, 1988.

LISPECTOR, Clarice. Entrevista concedida a Júlio Lemer. São Paulo: TV Cultura, 1977.

LUKÁCS György. Lukács e o cinema. In: CHAGAS, Rodrigo (org). Cinema, Educação \& Arte. Boa Vista: editora da UFRR, 2013. Tradução Lívia Contrim.

LUKÁCS, George. Estética: la peculiaridad de lo estético. Barcelona: Ediciones Grijalbo, 1966. v.1.

LUKÁCS, George. Estética: la peculiaridad de lo estético. Barcelona: Ediciones Grijalbo, 1966. v.2.

LUKÁCS, George. Estética: la peculiaridad de lo estético. Barcelona: Ediciones Grijalbo, 1967. V.3.

LUKÁCS, George. Estética: la peculiaridad de lo estético. Barcelona: Ediciones Grijalbo, 1967. v.4.

MARX, Karl. Contribuição à crítica da economia política. São Paulo: Expressão Popular, 2008. 
O quarto de Jack. Lenny Abrahamson. A24. Estados Unidos. 118 min, 2015.

MÉSZÁROS, István (2000). A crise estrutural do capital. Outubro: Revista do Instituto de Estudos Socialistas, São Paulo, n. 4. pp. 07-15.

SANTOS, Deribaldo. Estética em Lukács: a criação de um mundo para chamar de seu. São Paulo: Instituto Lukács, 2018.

VIEIRA PINTO, Álvaro. O conceito de tecnologia. Rio de Janeiro: Contrapontos, 2008.

\section{NoTAS}

1 Lukács (1967, v.1, v.2, v.3, v.4) entende como meio homogêneo o seguinte: um filtro que lapida o modo corriqueiro com que o vivente contempla o mundo em seu entorno cotidiano. Graças ao poder orientador e evocador dessa filtragem, o modo habitual do sujeito se relacionar com o mundo transforma-se e ele tem a possibilidade de acessar novos conteúdos que ampliam seu universo vivencial. Sob o efeito dessa lapidação mediadora, o receptor torna-se apto a receber os novos conteúdos sugeridos pelo filtro mediador. $\mathrm{O}$ resultado é que os sentidos e os pensamentos do vivente cotidiano são rejuvenescidos. $\mathrm{O}$ meio homogêneo, portanto, é o responsável por dotar o receptor da capacidade de reconhecer e desfrutar de um conjunto de novidades esteticamente apropriadas ao humano.

2 Não há como se debater aqui o caso da fotografia artística que, por sua força refigurativa, tem por obrigação estética que antropomorfizar. Consideremos, para efeito deste ensaio, apenas a fotografia que se pretende ótico-mecanicamente fiel à realidade.

3 Toda determinação, para que possa proteger sua precisão e univocidade, precisa conter, dialeticamente, elementos de indeterminação. A classe das determinações estéticas não foge a essa incorporação dialética. Determinação e indeterminação são, portanto, funções da totalidade intensiva. $\mathrm{O}$ caso artístico, indubitavelmente, mostra princípios formuláveis com precisão, não obstante, desconhece qualquer regra geral universalmente aplicável que lhe confira caráter formalista. Quando o criador tenta uma descrição precisa de seus personagens ocorre não uma determinação, senão uma hiperdeterminação que, na maioria das vezes, se inclina para o supérfluo.

4 A relação entre homem-inteiro, experimentada no cotidiano, e o homem-inteiramente, usufruidor das objetivações superiores, se dá de modo recíproco. A arte é o veículo que condensa e abriga a transição de um momento a outro. Isto é, o tráfego da condição de homem-inteiro à condição de homem-inteiramente. Em resumo, é o momento em que o ser social imerso em sua vida cotidiana (homem-inteiro), acessa, ainda que momentaneamente, um mundo qualitativamente distinto do da cotidianidade, um mundo apropriadamente ao humano. Em uma expressão: um mundo em que o sujeito humano possa se sentir homem-inteiramente.

5 Por sua performance no cinema mudo, foi aproximado a Charlie Chaplin.

6 No entendimento do autor, a "linguagem" artística do filme é, exatamente, o seu meio homogêneo.

7 Adverte-se que a utilização de tal exemplo não pretende classificá-lo artisticamente ou compará-lo ao $O$ ditador de Chaplin. Pretende-se apenas, com um filme de nossa época, ilustrar o que o debate lukasciano denomina de atmosfera psíquica. 